Article

\title{
Voice or Voice-Over? Harnessing the Relationship between a Child's Right to Be Heard and Legal Agency through Norwegian Bullying Cases
}

\author{
Sevda Clark \\ Faculty of Law, University of Oslo, 0130 Oslo, Norway; E-Mail: sevda.clark@nchr.uio.no
}

Submitted: 31 March 2017 | Accepted: 25 July 2017 | Published: 26 September 2017

\begin{abstract}
This article offers an analysis of the child's right to be heard under Article 12 of the Convention on the Rights of the Child and its application in Norway, through a case study of bullying. The methodology combines a "top-down" legal interpretation of Article 12 in addition to an analysis of Section 9a of the Education Act, juxtaposed with bottom-up approaches. First, a legal analysis of Article 12 and the General Comments of the Convention on the Rights of the Child Committee is provided, with a view to demonstrating the strength of the connection between agency and voice. Looking from the bottom up, therefore, the article then pursues the voices of the bullied children themselves. It places its ear to the ground, so to speak, through an examination of complaints submitted by children to the Ombudsman for Children, in order to "hear" the voices of children subjected to bullying at school, before they are formulated in legal terms before judicial bodies. Finally, I offer a close reading of the report on Section 9a commissioned by the Norwegian Government, published in a 2015 Report (the "Djupedal Report") in tandem with the leading Supreme Court 2012 decision on bullying, so as to critically examine the fulfilment of Article 12 in Norway. In the final analysis, I argue that in Norwegian bullying cases, though the child has the legal right to be heard, there is no voice, due to the limitations of legal agency for children pursuant to Article 12 of the Convention on the Rights of the Child.
\end{abstract}

\section{Keywords}

bullying; child rights; legal agency; Ombudsman; right to be heard

\section{Issue}

This article is part of the issue "Promoting Children's Participation in Research, Policy and Practice", edited by Jo Aldridge (Loughborough University, UK).

(C) 2017 by the author; licensee Cogitatio (Lisbon, Portugal). This article is licensed under a Creative Commons Attribution 4.0 International License (CC BY).

\section{Who's Afraid of the Third Optional Protocol (OP3) Convention on the Rights of the Child (CRC)? The Puzzle of Norwegian Non-Ratification}

A motivation for this study, and serving as its background, is the Norwegian Government's persistent scepticism and, as of 2016 ("The government will not give children the right to appeal to the UN," 2016), its dismissal of its ratification of the OP3 CRC on a communications procedure (adopted by the United Nations General Assembly on 19 December 2011 and entered into force 14 April 2014). Since 2010, there has been a steady stream of civil society advocacy for the Norwegian Government to ratify this new Protocol, when the communications procedure made its entrance onto the domes- tic political stage (dated from the answer by the Minister for Foreign Affairs in Parliament to a question regarding whether the government would assume a proactive role in the then ongoing negotiations in the Human Rights Council to institute an appeal mechanism to the CRC; see Stortinget.no, 2013). In a symbolic gesture two years later, on 24 November 2012, the succeeding Foreign Minister was given pens from various youth organisations to encourage Norway's signature and ratification of the new instrument that establishes a communications procedure. The domestic political landscape was coloured by a sense of confrontation, since earlier in 2012 when the OP3 CRC was opened up for signature, with an uncommon animosity between the Government and civil society. When Norway was preparing for its presentation 
of its Universal Periodic Review Mid-term Report, it was faced with a joint NGO platform consisting of Amnesty International, boycotting cooperation with the Norwegian authorities so as not to legitimise their report. In addition to being "highly unusual in a Norwegian context, where transparency and dialogue are important elements in [Norwegian] democracy" this spelled an unusually unconstructive beginning for OP3 CRC, thereby adversely affecting the deliberations. So, upon the conclusion of debates in Parliament on 24 November 2012, which resulted in Parliament requesting the government to conduct a study in the spring of 2013 highlighting the advantages and disadvantages of ratifying the OP3 CRC, the OP3 CRC found itself in uncommonly precarious political terrain in terms of children's rights protection in Norway.

The question of ratification-at least for the present-has been shelved by the current Norwegian Government and the future of OP3 CRC in Norway thus remains uncertain. The arguments against ratification advanced by successive Norwegian governments have been analysed from a political science perspective: dubbed the "Nordic Paradox", such a thesis has sought to explain this anomaly through arguments concerning democratic deficits and the issue of state power in the face of international oversight of domestic mechanism. As an example of this analysis, see (Schaffer, 2015). This article, too, seeks to understand the paradox of Norwegian scepticism to this new child rights treaty when perhaps it has little to fear from it on the international stage. Though it was not one of the first twenty states that ratified the CRC, Norwegian support of the CRC is exemplified by its incorporation of the Convention, in addition to the recent constitutionalisation of two of its guiding principles in Article 104 of the Norwegian Constitution. In short, my analysis is spurred by the question of how it is that a state which has a demonstrated commitment to children's rights in general, and to the CRC in particular, can take such a negative position with regard to a treaty that materialises the complaint rights of children as part of the child's right to be heard. Particularly given that the identification and interpretation of CRC rights by the Committee will become a source of law in Norway, regardless of Norwegian ratification. The authoritative interpretations of CRC provisions will become the bedrock of the CRC Committee's reasoning when it assesses Norway's state reports as part of its monitoring of the CRC. From the perspective, then, of the domestic protection of CRC rights, specifically Article 12 on the right of the child to be heard, Norwegian non-ratification makes less sense.

In attempting to make sense of the enigma of Norwegian resistance to this new treaty, I employ the case of bullying to argue along the lines, instead, that Norwegian non-ratification of OP3 CRC is less of a paradox than it appears. Rather, I seek to argue that non-ratification makes sense given the seemingly unshakeable nature of the legal disabilities of childhood-manifested most acutely in the blanket denial of legal agency to children. This article, then, is not so much about rights in school as it is about the right of the child to be heard, using bullying in Norway as a springboard for discussion. In the Western legal tradition, children have been incapable of initiating legal proceedings except when an adult representative initiates on their behalf. I frame my answer using this typology of legal agency, understood as the ability for children to sue in their own name. Though not a legal concept, legal agency offers a useful conceptual tool through which to avoid any confusion between the two separate legal concepts of the capacity to have rights ("legal personality") as opposed to the capacity to act on those rights, to complain ("legal capacity").

\section{Introduction}

I'm the monster? You're the monster! These children tried to warn you, but you wouldn't listen. No one ever listens to children! You think you're innocent?! You're accomplices! This certificate says that I have the fortune now! And there's nothing you can do about it! [to Violet] What do you think? Too diabolical? Give me some feedback!

This is a quote from Count Olaf from the 2004 film adaptation of Lemony Snicket's A Series of Unfortunate Events (Silberling, 2004), which speaks to the dire consequences to life and limb of failing to hear the voices of children. In the novel throughout, the children "speak" -including even the intelligent toddler, who speaks but is not understood by the adults who merely hear "Oots" and "Ohs". The children speak, but the adults fail to hear their voices at each and every instance. By way of an ingression into Article 12 of the CRC, when the Count asks Violet for her opinion in the aftershock of the forced marriage, would this satisfy the requirements of the provision? Article 12 reads:

1. States Parties shall assure to the child who is capable of forming his or her own views the right to express those views freely in all matters affecting the child, the views of the child being given due weight in accordance with the age and maturity of the child.

2. For this purpose, the child shall in particular be provided the opportunity to be heard in any judicial and administrative proceedings affecting the child, either directly, or through a representative or an appropriate body, in a manner consistent with the procedural rules of national law.

Prima facie, Count Olaf's request to hear Violet's views complies with Article 12 by offering the child a say, and there can thus be said to be compliance. However, the Count's question is clearly rhetorical; indeed, it adds insult to injury making it clear that the adult world is not substantively interested in what children have to say and, 
ultimately, it is the adult's narrative that prevails. The children speak but are very rarely heard.

The literary is not too far removed from the real. "It doesn't help to tell, they don't do anything anyway" are the chilling words that were spoken by Odin Olsen Andersgård who, in 2014, was driven to taking his own life as a result of his experience of bullying at school. Odin was one of 63,000 children who are, according to the Norwegian Institute of Public Health, said to experience bullying at any given time in Norwegian schools. The Norwegian Government presents children's rights in Norway as having the utmost importance, with an anti-bullying focus:

Norwegians consider children to be very important. They listen to children's views and try to include them when making decisions....There are very strict rules to prevent bullying at school, and just like in the UK, all schools must have an anti-bullying plan for teachers and pupils to follow. ("Norway's official websites abroad," 2016)

Norway also had the first anti-bullying campaign for children, which was instigated by students themselves (see comments of Knut Haanes, Deputy Ombudsman for Children in (Wakefield, 2007)). Yet, as Odin's case demonstrates, bullying remains a significant challenge to child rights protection in Norway.

Norway has been a pioneer in the field of children's rights. It has had two members, one the Chairperson on the Committee on the CRC. It has been said to be a "norm entrepreneur" (Ingebritsen, 2002, p. 11) in world politics, with Norwegians "being the first in the world to develop social policy measures to prevent bullying in schools" (Ingebritsen, 2006, p. 70) and Norway, being hailed by UNICEF in 2014 as "a true champion of children's rights with record donation" see ("Norway proves itself a true champion of children's rights with record donation," 2014). Further, it was the first country in the world to have a Children's Commissioner. The CRC was embedded in Norwegian law in 1991 when incorporated in the Human Rights Act, and in its 2014 revision Article 104 of the Norwegian Constitution was added, reflecting articles 12 and 3 of the CRC, expressing the child's right to respect for their human dignity, and enshrining their right to be heard in questions that concern them. This constitutionalisation is not insignificant as, in its transformation of rights into constitutional rights, having the legal effect that the right of the child to be heard acquires the status of lex superior, children enjoy the highest possible rank in the hierarchy of legal norms in the Norwegian jurisdiction. Further, as stated in the 2012 UNICEF Report on the Implementation of the CRC across 12 countries, "It is clear that Norway has a reasonably good legal framework to implement children's rights, in particular under Articles 3 and 12 of the CRC" (Lundy, Kilkelly, Byrne, \& Kang, 2012, p. 62). However, the Report also states the lack of measures available to ensure the enforcement of children's rights, and the absence of child-specific com- plaints mechanisms is highlighted as a particular concern. Few avenues are available to children seeking to complain about breaches of their rights: "Whilst incorporation and transformation had achieved good laws that were compliant with the CRC, (or at least with Articles 3 and 12), enforcement remains weak in the absence of effective monitoring, supervision and complaints mechanisms" (Lundy et al., 2012, p. 60). Finally, though there is increased use of the CRC in the Norwegian courts, "most litigation concerns Article 3, rather than the remainder of the CRC's provisions" (Lundy et al., 2012, p. 61).

This article offers an analysis of the child's right to be heard under Article 12 of the CRC and its application in Norway, through the case study of bullying. The methodology combines a "top-down" legal interpretation of Article 12 in addition to an analysis of Section 9a of the Education Act, juxtaposed with bottom-up approaches. First, a legal analysis of Article 12 and the General Comments of the CRC Committee is provided, with a view to demonstrating the strength of the connection between agency and voice. The article then pursues the voices of the bullied children themselves. It places its ear to the ground, so to speak, through an examination of complaints submitted by children to the Ombudsman for Children, in order to "hear" the voices of children subjected to bullying at school, before they are formulated in legal terms before judicial bodies. Finally, I offer a close reading of the report on Section 9a commissioned by the Norwegian Government, published in 2015 Report (the "Djupedal Report") in tandem with the leading Supreme Court 2012 decision on bullying, so as to critically examine how well Article 12 fares in Norway. In the final analysis of the article, I argue that though the child has the legal right to be heard in Norwegian bullying cases, there is no voice due to the limitations of legal agency for children pursuant to Article 12(2) CRC.

\section{Children in the Legal Process}

Traditional legal assumptions, what has been termed "liberal legal ideology" (Clark, 2015), have worked to deny legal capacity to children and have meant that children by definition and virtue of their legal status have been rendered ineligible to participate in legal proceedings. Otherwise referred to as the legal disabilities of childhood, these barriers fall short of international standards of child rights protection, most particularly Article 12 of the CRC, which enshrines a child's right to be heard. Jane Fortin characterises children's involvement in family law proceedings as a ladder (Fortin, 2009, pp. 248-249), evocative of Roger Hart's ladder of young people's participation (Hart, 1997). The different ways of being heard represent the ladder's rungs: the bottom rung being no views expressed to the court, progressing upwards to more direct involvement through party status, and ultimately to the ability to litigate on their own behalf as the uppermost rung of the ladder. Family law scholars Parkinson and Cashmore do not view Fortin's ladder as 
a hierarchy of virtue, and assert instead that there can be a smorgasbord of approaches to hearing the voices of children in legal proceedings, informed, not least, by resource constraints (Parkinson \& Cashmore, 2008). However, the point of the ladder is to elevate the child's legal involvement-it is not an end in itself, but exists as a tool to be used as a means to children having full recognition as rights holders before the law. Seen in this light, legal agency-the uppermost rung-must be provided for in order that children be elevated to their status as rights holders, particularly in cases where the state's legal machinery is not already engaged in family law or juvenile justice proceedings. Bullying provides a useful example of a case where children have reason to be complainants in their own right, without having been drawn into the legal system as defendants or participants in a divorce proceeding, for example.

\section{Voice and Agency: Forging the Connection}

The universal right to legal agency, defined as having both legal personality and legal capacity can be said to be a new norm in international human rights law that is also extended to children (Clark, 2015). Though this right is not expressly granted in the CRC (cf. Article 12 of the Convention on the Rights of Persons with Disabilities), the child's right to legal agency was implicit in the extension of communication procedures to children from their very inception in the UN system. As elucidated by the CRC Committee ("the Committee") in its General Comment No. 3 on General Measures of Implementation:

For rights to have meaning, effective remedies must be available to address violations. This requirement is implicit in the Convention and consistently referred to in the other international human rights treaties. Children's special and dependent status creates real difficulties for them in pursuing remedies for breaches of their rights. So states need to give particular attention to ensuring that there are effective, childsensitive procedures available to children and their representatives. These should include the provision of child-friendly information, advice, advocacy, including support for self-advocacy, and access to independent complaints procedures and to the courts with necessary legal and other assistance. (General Comment No. 5 (2003) General measures of implementation of the Convention on the Rights of the Child (arts. 4, 42 and 44, para. 6), 2003, para. 24) (emphasis mine)

As is evident here, in as early as 2003 the Committee moves beyond an implied right to legal agency, to stipulating the provision of mechanisms for its realisation.

\subsection{Article 12}

Thus, states are required to provide children access to judicial and quasi-judicial complaints procedures, with- out qualification as to age. This is further supported by Article 12 of the CRC on the child's right to be heard, one of the four "general principles" of the CRC, which "highlights the role of the child as an active participant in the promotion, protection and monitoring of his or her rights" (General Comment No. 5 (2003) General measures of implementation of the Convention on the Rights of the Child (arts. 4, 42 and 44, para. 6), 2003, para. 12) (emphasis mine). This stems from the Convention's recognition of "the child as a subject of rights, and the nearly universal ratification of this international instrument by States parties emphasizes this status of the child, which is clearly expressed in article 12" (General Comment No. 12 (2009) The right of the child to be heard, 2009, para. 18). Children are to be actively engaged in the process of protection and monitoring of their rights, strengthened by the proviso that "Involvement of and consultation with children must also avoid being tokenistic" (General Comment No. 5 (2003) General measures of implementation of the Convention on the Rights of the Child (arts. 4, 42 and 44, para. 6), 2003, para. 12), distinguishing between "listening" as an end in itself, and as a means:

But appearing to "listen" to children is relatively unchallenging; giving due weight to their views requires real change. Listening to children should not be seen as an end in itself, but rather as a means by which States make their interactions with children and their actions on behalf of children ever more sensitive to the implementation of children's rights. (General Comment No. 5 (2003) General measures of implementation of the Convention on the Rights of the Child (arts. 4, 42 and 44, para. 6), 2003, para. 12)

Hence, it is not merely that the child should "express" her views (Art. 12(1)), but Article 12 stipulates that she is to be listened to, and heard (Art. 12 (2)). Accordingly, the concept of "voice" used in this article is that of legal voice. It posits that for children's voices to be meaningful in the context of the Article 12 "right to be heard", children do not merely have the right to "express their views", with respect to the Article 12 qualification of "matters that affect them". Rather, children have the right to have their voices "heard" by an adjudication body: "either directly, or through a representative" as per Art. 12 (2). This concept of voice is to be distinguished from political "participation" in that it hinges on the active participation of the child in the legal process through the provision of legal agency to children (see Section 4.3 below).

\subsection{Lifting the Lid on Article 12: General Comment No. 12 (2009) on the Right of the Child to Be Heard}

The legal interpretation of Article 12 rendered by the CRC Committee in General Comment No. 12 (2009) further supports this claim of the centrality of legal agency to Article 12. It highlights seven elements of the right to be 
heard, which can be seen to be central to the provision of legal agency to children, as follows: namely, (i) Article 12 as a rule of procedure; (ii) the necessity of the provision of children's access to complaints procedures; (iii) the presumption of capacity; (iv) the non-imposition of an age-limit; (v) the inadequacy of simply "listening" to children; (vi) how the child must be heard; and (vii), the child's right to be heard "directly". First, as one of the four general principles of the CRC, the Committee reinforces the procedural quality of Article 12: "this article establishes not only a right in itself, but should also be considered in the interpretation and implementation of all other rights" (General Comment No. 12 (2009) The right of the child to be heard, 2009, para. 2). It thereby "provides the methodology for hearing the views of the child or children and their inclusion in all matters affecting the child" (General Comment No. 14 (2013) on the right of the child to have his or her best interests taken as a primary consideration (art. 3, para. 1), 2013, para. 43) (emphasis mine).

Secondly, one of the five steps enumerated for the implementation of Article 12 is the provision by states of legislation to "provide children with complaint procedures and remedies", and that "children should have the possibility of addressing an ombudsman or a person of a comparable role in all children's institutions...in order to voice their complaints" (General Comment No. 12 (2009) The right of the child to be heard, 2009, para. 46). Thus, the "child must have access to appeals and complaints procedures which provide remedies for rights violations" (General Comment No. 12 (2009) The right of the child to be heard, 2009, para. 47).

This is in turn inextricably linked to one of the core obligations imposed upon states by Article 12, namely "to review or amend their legislation in order to introduce mechanisms providing children with...procedures for complaints, remedies or redress" (para. 48). Consequently, the wording: "in a manner consistent with the procedural rules of national law" in subsection 2 of Article 12 cannot be used as an obstacle to accommodation of the legal agency of children as it "should not be interpreted as permitting the use of procedural legislation which restricts or prevents enjoyment of this fundamental right" (para. 38). Where such legislation exists, often supported by deeply-held views about childhood vulnerability, states are advised that in order to fulfil these obligations they should adopt a number of strategies, not least of which is to "combat negative attitudes...to change widespread customary conceptions of the child" (General Comment No. 12 (2009) The right of the child to be heard, 2009, para. 49).

The presumption of capacity is the third element of the Committee's legal analysis of Article 12 that is indispensable to legal agency. The wording in Subsection 1 of Article 12, "capable of forming his or her own views", is not to be read as a limitation to capacity, which means that one "cannot begin with the assumption that a child is incapable of expressing her or his own views. On the contrary, States parties should presume that a child has the capacity to form her or his own views and recognize that she or he has the right to express them; it is not up to the child to first prove her or his capacity" (para. 20).

Additionally, General Comment No. 12 makes it clear that the right is to extend to all children, regardless of their age and that Article 12 imposes no age limit on the right of the child to express her views. States parties are "discourage[d] from introducing age limits either in law or in practice which would restrict the child's right to be heard in all matters affecting her" (para. 21). Pre-verbal infants also come under its banner of protection, and "consequently, full implementation of article 12 requires recognition of, and respect for, non-verbal forms of communication including play, body language, facial expressions, and drawing and painting, through which very young children demonstrate understanding, choices, and preferences" (para. 21).

Another relevant element for our purposes is the ambit of the clause "being given due weight in accordance with age and maturity of the child", which is to be read in light of the presumption of capacity. Accordingly, it "stipulates that simply listening to the child is insufficient; the views of the child have to be seriously considered" (para. 28). That is to say, the child must be heard, their views being assessed on a case-by-case basis. As to how their view must be heard, this is provided for in subsection 2 of Article 12, which specifies the right "to be heard in any judicial and administrative proceedings affecting the child". This applies to any and "all relevant judicial proceedings.... without limitation", and indispensably, for our purposes, "applies to proceedings which are initiated by the child...as well as to those initiated by others which affect the child" (para. 33). This right is to be facilitated by an appropriate environment, both accessible and childappropriate (para. 34). Adult-oriented judicial and administrative systems will not suffice.

Finally, subsection 2 of Article 12 provides for the child being heard directly, pursuant to the wording "Either directly, or through a representative or an appropriate body". In General Comment No. 12, the Committee "recommends that, wherever possible, the child must be given the opportunity to be directly heard in any proceedings" (para. 35).

\subsection{Voice: Participation versus Legal Agency}

The right to be heard, pursuant to this interpretation of Article 12 , is to be distinguished from its common association with political "participation". As the Committee makes clear in General Comment No. 12, the drafting history of the CRC supports this distinction; indeed, the proviso "in all matters affecting the child" (Art. 12(1) was added to ensure "that no general political mandate was intended" (para. 27). However, the right to be heard is used often in the sense of consultation with children, where "the views expressed by children may add relevant perspectives and experience and should be con- 
sidered in decision-making, policymaking and preparation of laws and/or measures as well as their evaluation" (para. 12)-procedures that "are usually called participation" (para. 13). This view of Article 12 is referred to in the so-called "Three Ps" of the CRC, "provision, protection and participation", and is reflected in current practice:

A widespread practice has emerged in recent years, which has been broadly conceptualized as "participation", although this term itself does not appear in the text of article 12. This term has evolved and is now widely used to describe ongoing processes, which include information-sharing and dialogue between children and adults based on mutual respect, and in which children can learn how their views and those of adults are taken into account and shape the outcome of such processes. (General Comment No. 12 (2009) The right of the child to be heard, 2009, para. 3)

This view is not, however, without its critics: Nigel Cantwell (then-Coordinator of the NGO Group for the $\mathrm{CRC}$, having taken part in the drafting) makes the case that participation presents us with cause for alarm as an example of rights inflation that is putting the human rights consensus at risk (Cantwell, 2011, p. 42). Cantwell details the drafting history of General Comment No. 12from being the theme chosen for the 2006 Day of General Discussion for the CRC Committee, to its tumultuous deliberations and approval three years later. He then expresses disapprobation at elements of the Report which followed, which suggested an inflationary rights agenda, namely the full-participation of children in "all aspects of society" through a "leap" of an interpretation of Article 12, that "The new and deeper meaning of this right [to participate] is that it should establish a new social contract" (Day of Discussion on the right of the child to be heard, 2006, p. 2):

This is arguably quite a leap. One wonders what other CRC rights may suddenly be deemed to have "new and deeper" meanings, what those meanings might allegedly imply, and whether States Parties to the treaty are prepared to accept that they knowingly signed up to them. Clearly, if this kind of rights inflation is accepted, it will be almost impossible to avoid substantially sapping the strength of the original right in question and to engage states through credible advocacy. (Cantwell, 2011, p. 56)

In the end, "there seemed to be a recognition that matters were getting out of hand" and fortunately (as far as Cantwell's critique goes) the text that resulted in the form of General Comment No. 12 demonstrates that the "Committee successfully resisted an "inflationary" mindset and settled on a text that is, overall, realistic and wellfounded" (Cantwell, 2011, p. 56).

Cantwell's critique of interpretations of Article 12 is levelled at the political elements of this form of par- ticipation, as against constructions of the right that "can be considered as the symbol for [children's] recognition as rights holders", which "implies, on the long term, changes in political, social, institutional and cultural structures" (Day of Discussion on the right of the child to be heard, 2006, p. 2). Consequently, Article 12 is not to be construed as freedom of expression. If anything, Article 12 presents us instead with a right that grants legal agency in cases that directly impact upon a child, and particularly when administrative and judicial decisions are being made about their lives. Cantwell elucidates this through his reading of the drafting history of the CRC and the following points are manifested, among others: that Article 12 "is not a restatement of the general right to "freedom of expression" but is directly linked to the context and requirement of consultation with the child". Secondly, "the 'matters' it seeks to refer to are clearly meant to be those that are directly pertinent to the life of the child concerned, not general issues that may have ramifications for children" (Cantwell, 2011, p. 55). For the most part, this is in line with the interpretation that the CRC Committee formally offers in General Comment No. 12 (see Section 4.2).

Article 12 is dubbed a number of labels, which both label and in so doing, interpret the provision. An analysis of the language used to describe Article 12 across all the General Comments of the CRC Committee thus affords an alternative means through which to ascertain the legal content of Article 12. Each General Comment, with the exception of a few, devotes a section to Article 12 as one of the general principles of the Convention, in light of which every substantive right must be interpreted. I study the language used in the titles, the pseudonyms if you will, of how Article 12 is labelled in all the CRC General Comments to date. My survey of the title language is supplemented with a detailed reading of the sections' contents. This preliminary analysis of language reveals the minority of the "participation" element of interpretation: only two percent of General Comments use the word "participate" in their descriptions of Article 12 . Not surprisingly perhaps, the most recent "General Comment No. 20 (2016) on the Implementation of the Rights of the Child during Adolescence" is the only General Comment to have used this language to describe Article 12. The survey is limited to the language used in the titles of the sections devoted to Article 12, as one of the four general principles of the CRC, the results of which are shown in Figure 1.

This preliminary survey of the title language is useful as a way of approaching the interpretation of Article 12 in the context of General Comments which can be varied, broad and, at times, disjointed. Notably, the predominance of the language of "right to" and "be heard" further supports the claim that Article 12 grants the right to be heard in judicial and quasi-judicial settings, and is to be distinguished from political participation in the form of the freedom to "express views".

Nonetheless, as one would expect, the language used in the General Comments becomes more varied, 
Language Describing Art. 12 CRC in CRC General Comments

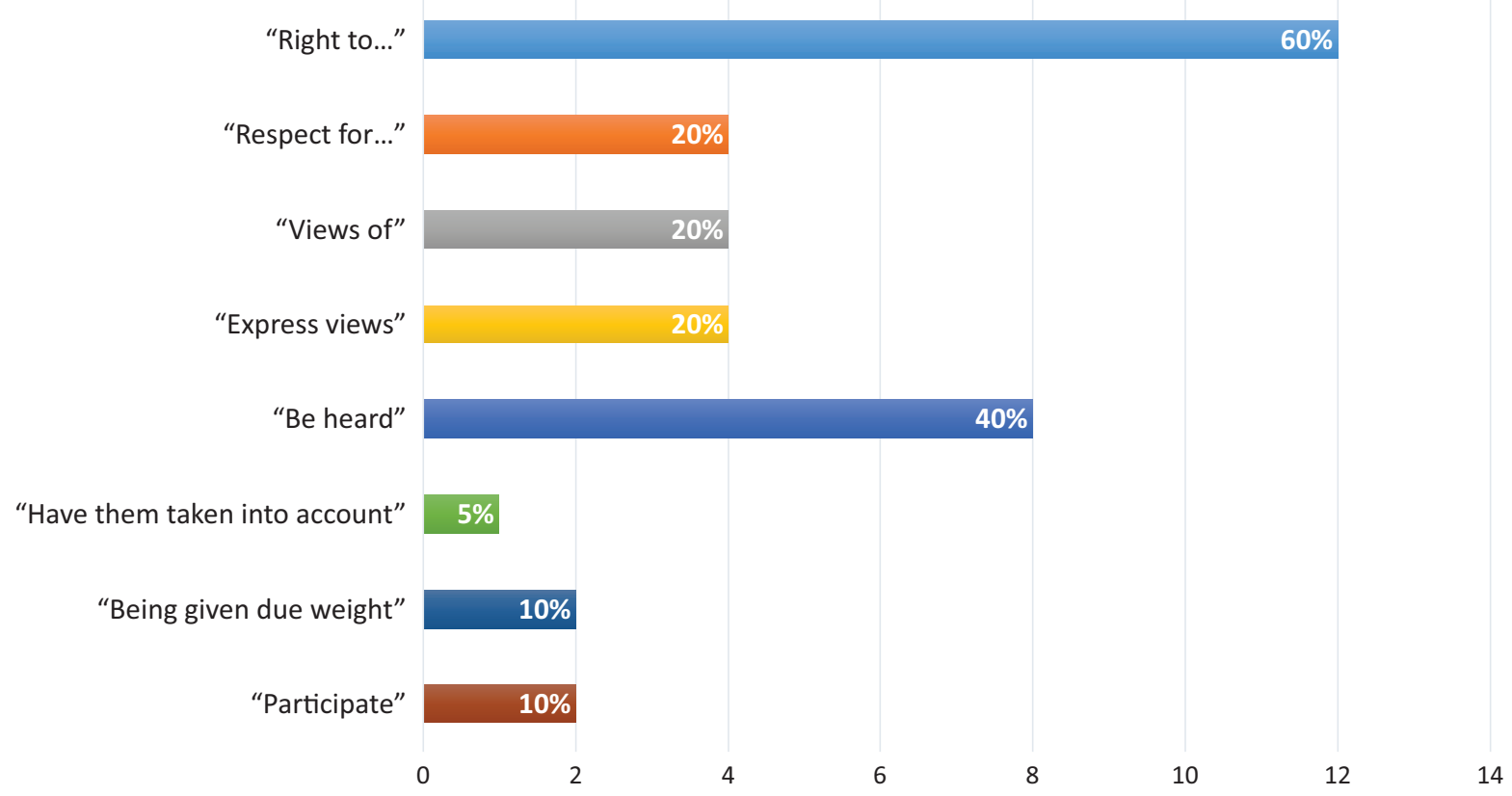

Figure 1. Language analysis of references to Art. 12 in CRC General Comments (1-20).

and at times difficult to generalise upon examination of the contents of these sections. A more detailed survey of the General Comments of the CRC Committee reveals more of a focus on participation. For example, "General comment No. 19 (2016) on Public Budgeting for the Realization of Children's Rights (art. 4)" equates, and limits, the right to be heard as the right to participate: "States parties should regularly hear children's views on budget decisions that affect them, through mechanisms for the meaningful participation of children at the national and subnational levels. Participants in those mechanisms should be able to contribute freely and without fear of repression or ridicule and States parties should provide feedback to those who participated. In particular, States parties should consult with children who face difficulties in making themselves heard, including children in vulnerable situations" (para. 52), and should ensure the provision of user-friendly information (para. 54), and freedom of information (para. 55). Regrettably, no reference is made throughout to children's access to remedial procedures. General Comment No. 15 (2013) on the Right to Health, too, lists only the participation elements: "Article 12 highlights the importance of children's participation, providing for children to express their views and to have such views seriously taken into account, according to age and maturity". Promisingly, in "General Comment No. 14 (2013) on Best Interests of the Child (art. 3)", reference is made to subsection 2, which is detailed under the section "Procedural safeguards to guarantee the implementation of the child's best interests". However, the right of the child is, again, delimited to the "right of the child to express his or her views" which is in turn linked to representation: "the child wishes to express his or her views and where this right is fulfilled through a represen- tative". No mention is made of the child's direct right to legal capacity and agency as crucial to the right to be heard (General Comment No. 14 (2013) on the right of the child to have his or her best interests taken as a primary consideration (art. 3, para. 1), 2013, para. 90).

General comment No. 16 (2013) on State Obligations Regarding the Impact of the Business Sector on Children's Rights is the most promising: it separates the participation element from the legal agency-political from legal voice. The Introduction and Objectives make this division clear:

Children are often politically voiceless and lack access to relevant information. They are reliant on governance systems, over which they have little influence, to have their rights realized. This makes it hard for them to have a say in decisions regarding laws and policies that impact their rights. In the process of decision-making, States may not adequately consider the impact on children of business-related laws and policies, while, conversely, the business sector often exerts a powerful influence on decisions without reference to children's rights. (para. 4(b))

This is immediately followed with a direct link to lack of children's legal agency:

It is generally challenging for children to obtain remedy-whether in the courts or through other mechanisms-when their rights are infringed upon, even more so by business enterprises. Children often lack legal standing, knowledge of remedy mechanisms, financial resources and adequate legal representation. (para. 4(c)) 
Thus, one of the stated aims of the said General Comment No. 16 (2013) is to provide states with guidance specifically on how to "Ensure access to effective remedy for children whose rights have been infringed by a business enterprise acting as a private party or as a State agent."

States should ensure that adolescents are involved in the development, implementation and monitoring of all relevant legislation, policies, services and programmes affecting their lives, at school and at the community, local, national and international levels. The online environment provides significant emerging opportunities for strengthening and expanding their engagement (General comment No. 16 (2013) on State obligations regarding the impact of the business sector on children's rights, 2013, para. 23)

In contrast, General Comment 20 (2016) on adolescent rights, connects the right to a remedy with legal agency: "The measures should be accompanied by the introduction of safe and accessible complaint and redress mechanisms with the authority to adjudicate claims made by adolescents, and by access to subsidized or free legal services and other appropriate assistance" (General comment No. 20 (2016) on the implementation of the rights of the child during adolescence, 2016, para. 23) (my emphasis). Accordingly, adolescents are to have the right to make claims directly to judicial bodies specifically empowered to adjudicate such cases.

Finally, though joint General Comment No. 18 (2014) on Harmful Practices (with the Convention on the Elimination of Discrimination against Women) does not devote a section to Article 12, direct reference is made to legal agency as a component of the right to be heard:

Victims seeking justice for violations of their rights as a result of harmful practices often face stigmatization, a risk of revictimization, harassment and possible retribution. Steps must therefore be taken to ensure that the rights of girls and women are protected throughout the legal process, in accordance with articles 2 (c) and 15 (2) and (3) of the Convention on the Elimination of All Forms of Discrimination against Women, and that children are enabled to effectively engage in court proceedings as part of their right to be heard under article 12 of the Convention on the Rights of the Child (Joint General Recommendation No. 31 / General Comment No. 18 on harmful practices, 2014, para. 85) (emphasis mine).

As the foregoing analysis has tried to demonstrate, legal agency-defined as the right of children to submit complaints directly to judicial and administrative bodies-is an indispensable part of the Article 12 right to be heard. Though there has been much scholarship on the provision as a participation right, the tectonic shifts it heralds, in terms of granting legal agency to children, has received little or scant attention. Laura Lundy has expressed criticism of the "abbreviations for Article 12" such as "pupil voice" as having the "potential to diminish its impact as they provide an imperfect summary of the full extent of the obligation" (Lundy, 2007, p. 927) thereby concluding that voice alone is not enough. She successfully advocates the importance of Article 12 in the educational context, but her analysis too runs the risk of weighing in too heavily on "voice" and subsection 1, at the expense of agency and subsection 2 . This section has attempted to remedy that deficit. Through the analysis of the "abbreviations" used by the CRC Committee in its General Comments for Article 12, supplemented with a deeper reading of the articulations of the content of that right, I hope to have made at least as strong a case for legal agency as there is for participation in legal interpretations of Article 12. I take up the challenge keenly expressed by Kay Tisdall in her evaluation of Article 12 as participation rights, that "we need to question why there are not more radical notions of children and young people's involvement in their social, economic, cultural and political contexts than to have due regard to their views" (Tisdall, 2015, p. 197). The legal agency of children is radical, as it deracinates the legal disabilities that lay at the legal foundations of Western liberal legal ideology. Having thus established the centrality of legal agency to Article 12, I now proceed with using this as the lens through which to examine the right of the child to be heard in bullying cases in Norway.

\section{Tracing Children's Bullying Complaints}

\subsection{Bullying at Law}

The analysis that follows is not concerned with providing an extensive overview of the bullying laws in Norway as much as it concerns the right of the child to be heard, using bullying in Norway as a springboard for discussion. Historically, bullying laws in Norway have been ignited by tragedies marked by the absence of hearing the voices of bullied children, which have bruised the public consciousness and have prompted a spate of political and legal initiatives. The year 1994 witnessed a national tragedy of the horrific murder of five-year-old Silje Redergard at the hands of two six-year-old boys with whom she was playing on a football field in Trondheim. Dubbed the Norwegian Bulger case, it sets the scene for the series of government actions taken to counter bullying in the decade that would follow. The new initiatives against bullying that it spurred began in 2002 and were driven directly by the voices of children themselves:

I think really the focus on bullying started with the pupils themselves because they made the Ombudsman for Children aware of the problem that was in Norwegian schools and we really felt that it was time to do something about it because it seemed like the adult community were ignoring the very sad 
fact that a lot of children really were scared to go to school. (Deputy Ombudsman for Children, cited in Wakefield, 2007)

The result was the Government-led "Manifesto against Bullying", which galvanised action against bullying and led to the introduction of the new law in Section 9a of the Education Act affording children the same rights in their workplace as adults have in theirs; namely, it afforded pupils the legal right to a safe, bully-free working environment. Thus, the first bullying legislation was expressly driven by the child's right to be heard-indeed it was children's voices themselves that was the catalyst for change. Once again in 2014, the despair of not being heard that led to Odin's suicide was thick in the public air, and mobilised the public once again into rallying against bullying. It resulted in the establishment of a government commission to consider the overall measures necessary to create a good psychosocial environment, and to prevent and address bullying and other incidents in schools. The resulting "Djupedal Report", entitled "To Belong: Means for a Safe Psychosocial School Environment" and published in 2015 , engaged closely with Section 9a and will be referred to at length in the analysis below, as it provides a useful literature survey of the field, in addition to providing inroads for discussing the legal implications of Section 9a, specifically children's complaint rights in context and in practice. The Commission, like the literature on bullying itself, comprised of a mix of experts from policy and educational backgrounds, but with a lawyer admitted to the Supreme Court, Tor Kielland, who specialises in employment law and bullying. Much of the literature on bullying is in the social sciences, education and psychology, with little legal literature available, with the exception of the report commissioned from the Faculty of Law, University of Oslo (Welstad \& Warp, 2010) by the Ministry of Education. Notably, for our purposes, the authors make the keen observation that "pupils' voices are in the background" in Section 9a cases; that although the children are the holders of legal rights, they:

Do not have the same perspectives and assumptions as adults to assert their rights. In matters pertaining to students' psychosocial environment there are stringent requirements for the role of responsible adults as competent communicators of children's rights. Adult persons and school employees have by virtue of their age and their position an ethical claim on the pupils. They can largely choose whether to apply this in favor of the pupils or to their own or possibly school interests. For example, it may be the case that children and young people choose to express what the others think are perceived as a desirable response to a greater extent than their own, sincere experiences of a situation. (Welstad \& Warp, 2010, p. 94)

Effectively, without using the terms, Welstad and Warp speak of a "voice-over" effect by adults on a child's voice due to the significant power imbalances in this context. They thus recommend the sharpening of requirements of the legislation by making the child's right to be heard an independent part of Section 9a that "will have a symbolic value that sends the signals of the importance of emphasising the students' own voice in matters affecting their school environment" (Andenæs \& Møller, 2016, p. 79). More recently, in Rights in School, Andenæs and Møller provide a broad interdisciplinary account between pedagogical, legal and political perspectives, and briefly discuss the Section 9a right to a good psychosocial environment at school (Andenæs \& Møller, 2016).

Turning now to the nucleus of the law, importantly, Section 9a provides children with "an individual right to a good school environment that promotes health, wellbeing and learning. The school will actively and systematically work to promote a good psychosocial environment where the individual student can experience security and social belonging" (Andenæs \& Møller, 2016, p. 182). Thus, its two important elements, being the individual child's subjective right, in addition to the responsibility of the school, are of the essence. Section 9a-1 reads: "All pupils attending primary and secondary schools are entitled to a good physical and psychosocial environment conducive to health, well-being and learning." Written into Section 9a-3 is the individual child as direct beneficiary of the law, entitled to a "good psychosocial environment, where individual pupils can experience security and social belonging". It is the student's subjective experience that needs to be met:

It's not that there is an adult at the school who decides whether a student has a good psychosocial school environment or not. In Proposition No. 72(2001-2002), the Ministry has stressed that it is the student whobased on their subjective experience-determines if the court is satisfied or not. If this principle had been altered, the pupil's position would be significantly weakened. It would also be problematic if an adult person could tell a child that she must endure. This could be a new infringement....Part of the child's dignity consists of recognising and respecting children and adolescents as rights holders, and Article 12 on the child's right to be heard. (Djupedal \& Norge, 2015, pp. 210-211)

Thus, it is to be the "voice" of the individual child that is to be the standard. Not the "voice-over" by adults in the school.

Secondly, it is the school's responsibility to "make active and systematic efforts to promote" the stated aim of Section 9a: "the school management is responsible for the day-to-day implementation" and individual school employees have a duty to investigate, notify and if possible intervene upon learning or suspicion of "offensive language or acts such as bullying, discrimination, violence or racism." Thus, Section 9a-3 comprises what is termed an action duty on the part of the school. Lastly, 
and importantly for our purposes, 9a-3 enshrines the school's obligation to make decisions:

Paragraph 9a-3 third paragraph contains an obligation for the school through the principal to make decisions under the Public Administration Act if the student or parent asks for measures related to the psychosocial school environment. Measures can also be requested by students and student groups. The threshold for considering something like a request from the student or parents that triggers the obligation to make decisions is low. It is the student or parents who decide whether they want a decision or not when the pupil's right are not met. Individual decisions must consider whether a school pupil was justly dealt with, and which measures may be incorporated for the student's right to be fulfilled. The measures shall be lawful, appropriate and sufficient for the student's rights to be met. A plain decision shall be made in accordance with the procedural rules for decisions in the Public Administration Act and the CRC. That means, the school will evaluate whether the measures would be best for the child, and the child should be heard, according to Articles 3 and 12 of the CRC. However, it is not the students' and parents' subjective experience that are the basis when deciding what action is initiated. This depends on what has happened, and is a professional assessment of what measures would be appropriate and sufficient. The plain decision may be appealed to the County. (Djupedal \& Norge, 2015, pp. 231-232) (Translated by the author)

Thus, it is the child's subjective "voice" which is to be the standard; the adults have a statutory obligation to "hear" and to act in the form of a reasoned individual decision. The current law and its so-called two-track approach, comprising of an action duty in addition to the separate duty to make decisions, are critically assessed in the Djupedal Report with a resulting recommendation for law reform that unites these currently existing twotracks into a single procedure. Notably, the recommendations of the Djupedal Report were catalytic as the critical background to the new revised Education Act, since drafted by the Ministry of Education and approved by Parliament and entered into force 1 August 2017. Thus, though the Report is not so much a legally authoritative source per se, it now has strengthened legal status as travaux préparatoires for the revised Section 9a. I now turn to the Report and its recommendations.

\subsection{The Djupedal Report (2015)}

The Djupedal Report published in 2015 identifies five major challenges. The first of which, the rule of law, will be the focal point of this discussion, as it aims at strengthening student's legal rights through a more effective complaints procedure under Section 9a. Though this is not directly tied to the Article 12 right to be heard by the
Commission, the measures proposed in the Report, more generally, are stated to be "From Human Rights to Practice", where the "Commission looks at what is needed for students' rights under the CRC and Education Act to be fulfilled in practice" (Djupedal \& Norge, 2015, p. 142). Thus, the Report has at the heart of its reform agenda the implementation of the rights of the Convention. In words that present a bleaker picture than the UNICEF Study of Implementation, the Commission states that

There is a need to clarify the central principles of the Convention in the Education Act. Reviews of the schools and county government decisions in 9a affairs show that CRC Article 3 to a small extent is being drawn upon, and that it is almost not visible that the student is heard, pursuant to Article 12, CRC...there is a need to strengthen Article 12 and the right of children to be heard in the Education Act. (p. 205)

The Report then cites the CRC's Committee's Concluding Observations on Norway in 2010, expressing concern at the implementation of Article 12:

The Committee is however concerned that children's right to be heard is not fully implemented in practice or effectively practiced in all phases of the processes of making decisions or arrive at arrangements for children's lives....The Committee recommends that the State party continue and strengthen efforts to implement fully article 12 of the Convention, and promote due respect for the views of children of all ages in administrative and judicial processes....The Committee recommends that the State party take into account the Committee's General Comment No. 12 from 2009, the child's right to be heard. (p. 205)

Overall, the Report makes a hundred or so recommendations to Parliament for the strengthening of children's legal protection at school. Speaking to the rule of law challenge, the specific recommendations made in Chapters 15 and 16 include the following: that the general principles of the Convention (including Article 12 right to be heard) are established by law in the Education Act, Sections 1 and 9a (p. 23); a new action duty is proposed with statutory requirements as to how schools should treat violations of students (p. 23); and finally, the recommendation that the existing complaints procedure be changed (p. 24).

The Report cites student dissatisfaction with school, among other sources, to demonstrate the ineffectiveness-indeed illegality-of schools' practice under Section 9a: "Only' two percent say they are satisfied with [their environment] at school. As for the students who feel that they are being bullied or harassed, the implication is that the requirements of the Education Act are not being met, and that school owners and schools are acting unlawfully. It is not acceptable"(p. 145). Further, adults in the schools have little knowledge of their obligations under the Act. 
The Individual complaints procedure under Section 9a, as it stands, is assessed and found to be wanting. Despite providing students with "strong legal rights" and legal protection (p. 198), the lack of knowledge on the part of schools and the concomitant lack of enforcement are identified as principal causes of the ineffectiveness of Section 9a:

Students have, in the Education Act strong rights that trigger duties for the school owner, the school and all of its employees. However, it is a challenge that regulatory compliance is not good enough, and that the rights and obligations in the Education Act Section 9a are not fulfilled. The Commission believes the responsibilities that school owners and all the staff at the school have must be clear for students to have a safe psychosocial school environment that promotes health, well-being and learning. The Commission believes there is a need to examine the contents of the student's right and the requirements for school owners and schools to ensure that students' rights are fulfilled. The Education Act is currently a law without legal tools to impose the implementation of measures in decisions or the like. It is necessary to provide better legal protection for students through a clearer system with effective complaints and inspection services. (pp. 146-147)

Thus, a child or her parents have the right to request the school to take action pursuant to Section 9a-3, and the school must make a decision by the Public Administration Act, where the school is to reach a decision on whether the students' rights are fully met, and which contains measures that should be fulfilled. However, as the Report indicates, there are no figures at the national or county levels that show how many decisions under Section $9 a-3$ are undertaken by schools every year:

Bergens Tidende conducted in 2013 a study in which they examined whether schools in the Bergen area made decisions under $\S 9 a-3$ third paragraph or not. They found significant differences. They found that 29 of primary schools had not made any decisions in the past three years, while a school had 29 decisions in the past year. There is no reason to believe that one school had so many more offenses than the other. The school with 29 decisions was, according to Bergens Tidende one of the schools with the lowest bullying figures in Bergen. When the school does not make decisions, it will be harder to complain, despite the fact that it is also possible to complain that the school has not made a decision within a reasonable time. Missing decisions are a challenge for legal certainty and effective legal protection. (p. 199)

Failing an effective decision, the students then have the right to appeal to the County Governors, a process which is found by parents to be costly and "little known and lit- tle used compared with the percentage of pupils in the student survey in 2014 who reported that they were violated or bullied two or three times a month or more. The same applies to previous years also. This can be interpreted as a legal challenge" (p. 249). The figures from the annual reports submitted by the County Governors to the Directorate of Education illustrate the number of complaints under Section 9a-3, which have since 2011 been about 100 per year nationally: "There are variations between county departments in terms of the number of complaints they have handled. One office has zero issues, while the average is approximately five to ten cases a year. Common for offices is that the cases are mainly related to Grunnskole [elementary and lower secondary school, ages 6-16] students. There are practically no complaints related to Videregående [upper secondary, ages 16-19] education in the past four years combined" (p. 249).

Thus, the Report suggests a new complaints procedure, which should be seen in connection with the changes taking place internationally related to children's human rights, specifically OP3 CRC where children have the right to appeal directly to the UN CRC Committee for state violations of their human rights when the national appeal possibilities are exhausted (p. 251). The Commission finds that the current scheme is not effective:

The Commission believes that in order for students' legal rights to be real, it is necessary to provide an effective safeguard against infringement, which means that there are legal tools that are powerful and can protect students when the school owner and the school did not meet their responsibilities. This means that there must be an independent body to complain to, and that this body must have legal instruments to ensure that its decisions are being met. This does not exist in the current Education Act. A body that deals with complaints that cannot enforce measures to protect the pupil, does not provide effective protection of students' rights. (p. 251)

The Report concludes that Norway would fall short of the effectiveness requirement for the domestic remedies that need to be exhausted in order for a complaint to be admissible under Article 7, OP3 CRC, where effectiveness is to be measured by the time and accessibility to children: the system must not be too lengthy or cumbersome, and must be known to children:

complaints regarding bullying in schools is one of the areas that children and young people are most concerned about. This suggests that the complaints procedure that exists, must be accessible to children and young people, and that it must be organized in such a way that they can understand it. The Commission believes that the considerations cited here, are important in determining how the complaints procedure for violations of school should be organized. (p. 251) 
The consequence of the finding of ineffectiveness would be that the Committee can then sidestep the requirement for exhaustion of domestic remedies. The Report thus recommends an overhaul of the Section 9a complaints procedure, with a view to improving the legal rights of students with the introduction of a new activity obligation, and a national system and where the Ombudsman for Children is recommended as the first instance authority empowered to make binding decisions in bullying cases, thereby giving the complaints procedure "teeth":

This is related to the introduction of activity obligation and the UN Children's Committee has stated that national complaint schemes must be an effective remedy that is child sensitive, ensures a child's need for a quick resolution of the matter and is available....By introducing a duty which clearly regulates how violations should be handled for that student's right to be fulfilled, the student and parents could complain if they feel this obligation is not fulfilled, and that the measures adopted are not appropriate and sufficient. Through a new duty of activity, at the first instance, here we will say the Ombudsman, all requirements regarding the proceedings will need to be satisfied, whether the measures are appropriate and sufficient to enable students to again have a safe psychosocial school environment, and whether the school / school owner's supervision has been inadequate compared with what expected by Chapter 9a. This corresponds to the Supreme Court's consideration in the Kristiansand judgment. The Ombudsman's decision can be appealed to the School Environment Complaints Board. (p. 194)

By establishing a national body to deal with complaints, it will be possible to build up a specialized expertise in this organ. The Committee sees that building up a specialized expertise can be important because these matters are complex and complicated. Feedback also suggests that county departments spend a lot of time to process each individual case. It would probably be more effective with an entity that has specialized expertise (p. 252)

Article 12 is thus viewed in the context of legal agency, with the need for an effective complaints procedure, in line with international legal developments in OP3 CRC. However, political participation is also addressed; that students are not afforded the right to participate is discussed in the Report as the third challenge, namely that students and parents are not involved sufficiently in the school's work with the psychosocial school environment and the prevention and handling of violations and bullying. "For students, the Committee would highlight the student's right to be heard in matters affecting them. The CRC is not sufficiently anchored in some schools. This may concern, for example, pupils not being allowed to express their opinion on how challenges in student culture are to be resolved, and that students and parents are informed and involved in following up the results of the student survey". (p. 147)

The Djupedal Report thus suggests reforms to the complaints procedure for children: clarifying internal procedures and allowing children and parents to complain to the Ombudsman, with a low threshold. It also advises the express inclusion of Article 12, as a guiding principle of the CRC into the text of 9a. However, the Report does not directly link these two. As we have seen, a central component of the Article 12 right is to provide the judicial and administrative forums for children to be able to submit complaints, and to have them heard in an effective and child-sensitive manner. What the Report characterises as due process rights can be seen as an element of the Article 12 right to be heard, as argued in section 2 above. That is to say, children have the right to legal agency in order to be able to initiate a claim against their school-as children-with a low threshold for complaints, and with hope for a speedy resolution of their case. Further, given also its constitutionally superior hierarchical status as lex superior, the Article 12 right to be heard as a means of grounding children's complaint rights, cannot be underestimated. Thus, we have in Article 12, an additional (and perhaps stronger) basis upon which legal agency for children subjected to violations of their human rights can be grounded. Critically, as noted above, the Report was the catalyst for law reform and the revised Section 9a: Prop.57 L approved by Parliament 9 June 2017 (Law 38), which will have the elevated legal status of as travaux préparatoires.

\subsection{Voicing Concerns: Child Complaints to the Ombudsman for Children}

To return to Fortin's image of the ladder of child involvement in judicial processes, children who have not been drawn into the machinery of legal procedures (through juvenile justice or family law proceedings, most commonly) struggle yet to find a ladder. Section 9a represents such a ladder within the educational context, and listening to the voices of children at the first stage of complaint affords a means of ascertaining which rung of the ladder most accurately represents the voices of bullied children. Currently, the Ombudsman does not have any powers to consider individual complaints from children: "The Ombudsman does not have the authority to decide cases or set aside decisions in the administration" (Section 1, The Ombudsman for Children, Norway Act and Instructions). Though the Djupedal Report recommended that the appeals to the County Governors be replaced with a specialised complaint procedure at the Office of the Ombudsman for Children, this was not taken up in the revised version of the law. However, children and young people up to eighteen years of age have been able to submit (anonymous) questions to the Ombudsman, online. The cases concerning bul- 
lying in schools that are analysed here are taken from the questions archive on the website of the Ombudsman for Children (www.barneombudet.no), and the bullying cases are mainly found under the theme "bullying" and "school", and cover the questions from October 2013 to October 2016.

The findings comprise a case digest of twenty-five cases. Of the cases, only two relate to a single incident, whereas twenty-three of the cases concern bullying by teachers and other pupils for at least a year or longer. The ages of the children submitting the complaints fall mostly within the fifteen to seventeen-yearold age bracket, with the youngest complainant being eleven years of age. There was one complaint received each from an eleven, twelve and thirteen-year-old, respectively. In twenty-one of the cases, the child stated that the teacher or the school ignored their complaint. Three children wanted to take legal action against the school and two children expressed a desire for civil action in the form of compensation. In one case, a sixteenyear-old girl was acting as a pseudo-guardian, voicing her concerns for her younger brother in seventh grade who had been bullied for several years. She describes the physical violence to which her brother was subjected: in 2015 , he was beaten and had to be airlifted to a hospital where they detected concussion and was in urgent need of nose surgery. The girl wrote that the school did not care and the father was shut out when he wanted to see the principal.

The children's voices are articulate, succinctly expressing the problems they are facing, as well as their dissatisfaction with the process at school. The desire to take the complaint further, reflects voices that are seeking remedies, and this is not limited to the older children. By way of example, the youngest of the complainants, expressed concerns that spoke to the gaps between school policies and practice. The eleven-year-old girl had been bullied since kindergarten by both students and teachers, and wrote that she felt that the school was just writing resolutions without much happening in practice. The Ombudsman for Children advised her that only when the school makes resolutions that do not work should she complain to the County Governor, and if that does not help, to contact the Ombudsman for Children again. This is quite a standard response to the questions submitted by the children.

From 2013 to 2016, we have a pool of twenty-five complaints submitted by children to the Ombudsman, spanning the ages that are most common among the complaints submitted to the County Governors (see Section 5.2 above). However, contrary to the findings from those very same reports, that "there were practically no complaints related to upper secondary education in the past four years combined" (Djupedal \& Norge, 2015, p. 249) (2011-2014, coinciding with the years examined here) complaints were submitted to the Ombudsman for Children by twenty-eight percent of students in that age bracket. This can indicate that the County Governor ap- peal process is too high a threshold. This is supported by the fact that only in one case did the seventeen-yearold indicate that complaints had been sent to the County Governor, indeed seven times, but to no avail, and with no consequence.

The genuine "voices" expressed by the children who are bullied at school can be seen as tokenistic in the sense that they are not "heard" as complaints in a formal quasi-judicial or judicial setting. Often, the responses they receive are templates, advising children that they should contact their school, and failing action, that they should contact their respective County Governors. Despite there being, here in the informal complaints to the Ombudsman for Children, a genuine expression of voice-absent their role as legal agents and being able to present their complaints before an adjudicator who can provide a decision granting relief-the voices of children are muffled and silenced. As this survey illustrates, this is reflected in the informal complaints submitted by children to the Ombudsman for Children, especially in the cases where these children's bullying complaints are not formally registered by the school system-indeed they are said not to have complained at all-and are therefore invisible. Looking up from the ground, then, the picture does not seem too promising for children's voice in bullying cases in Norway. Given that the "process of norm-setting, i.e. the creation of children's rights legal standards, tends to be top-down and adult-driven" (Vandenhole, 2015, p. 39), to conclude with the inverse approach, the only decision on bullying before the Norwegian Supreme Court will now be explored for the light it may shed on the child's right to be heard.

\subsection{Supreme Court "Kristiansand Decision" 2012}

The Norwegian Supreme Court case, called the Kristiansand decision (HR-2012-241-A-Rt-2012-146) is a historical verdict; the first case before the Supreme Court concerning compensation for bullying in schools. In this ground-breaking case, a bullying victim was granted over 900,000 kroner in compensation after the Supreme Court rejected the appeal from the municipality. The importance of the unanimous judgment lies in it being the first time a municipality was held to be responsible for bullying at school, and in its wake, there have been successful awards of compensation before district and appeal courts.

The case concerns that of an adult in his late twenties initiating a compensation claim against the Kristiansand Municipality for suffering post-traumatic stress disorder as the result of severe bullying experienced at school from six to eleven years of age. It was dismissed by the District Court at the first instance; though bullying had been established, the school staff were acquitted of any wrongful conduct or negligence. The applicant therefore appealed, upon which, the lower court decision was overturned by the High Court of Agder, finding against the Municipality on the grounds of negligence by the em- 
ployees by the doctrine of cumulative error, where "it is not necessary to prove each individual's fault or negligence" (para. 38). This decision is situated squarely in the original intent behind Section 9a of the Education $A c t$, whereby students are to be recognised as having employee rights in their working environment. The Court used the standard of care required by employers, with primary schools regarded as a "service", where the students were not afforded the good working environment to which they were entitled. Of the essence is that this case was brought by an adult in his late twenties, and is indicative of the temporal problem that children face in claiming their rights. This reflects the criticisms raised in the Ministry's Mapping of bullying cases before the County Governors (2010), as well as the Welstad Report (2011), where the length of time it takes for children's cases to be heard was highlighted as a fundamental problem (Djupedal \& Norge, 2015, pp. 249-250). Here, the applicant was well into adulthood by the time his voice could be heard, which raises the question: must a child reach adulthood in order to be able to claim her rights? Must she necessarily speak with an adult's voice? I argue that this challenges the central element of Article 12 , which affords children the right to be substantively heard by administrative and judicial bodies, as children. Section 9a affords children this right within the school environment.

What does this decision say about voice and legal agency? Only that, again, it is as an adult that the complainant is able to be heard, in addition to the marked absence of any references to the right of the child to be heard in bullying cases. Reference is made by the Court to Article 29 (1) CRC on Article 29 (1) that stipulates the right to a learning environment without tolerance for bullying, but the decision is thereby not formulated in terms of the right of the child to be heard. However, we may not want to throw the towel in just yet. The Kristiansand decision provides indirectly for the need to hear children who complain about bullying through adequate complaint mechanisms at the school and the local county level. Though this case is not an Article 12 case, indeed the only article from the CRC that is cited is Article 29(1), it can be read through an Article 12 lens. Namely, the school's repeated failure to act, in addition to the Court's reasoning as to why its chosen course of action was incorrect, sheds light upon how the student was not heard in practice.

\section{Conclusion}

The voices of children subjected to bullying in schools have not been heard; though the law in Section 9a provides for some form of agency, it has been grossly underused by children. This may speak to the cultural bedrock of childhood disabilities which is proving difficult to shift. Nonetheless, the existence of such a law could be seen as a promising step in the right direction signalling a developing law of legal agency for children in Norway who are subjected to bullying. Yet, the Government's law reform post-Djupedal leads to some uncertainty. In its response to the Djupedal Report, the Government announced its new measures to combat bullying in school in Circular dated 18 April 2016, in three areas: competence, support and guidance and legislative change. The Report's recommendations adopted with regard to a better complaint procedure were limited to a "clearer action obligation" in Section 9a; a "strengthened right of appeal"; and "strengthened pupils' rights". Read in light of the new revised Section 9a, these changes run the risk-at best-of being cosmetic (as opposed to the substantive changes proposed by the Report), re-wording the current text in line with the current mechanisms for complaint, indicated further by the right of appeal to the County Governor remaining the same. No suggestion was made of the direct reference to the guiding principles of the CRC. More cynically, according to the legal expert on the Djupedal Committee, Tor Kjelland, and a lawyer admitted to the Supreme Court specialising in employment cases and bullying, the most recent amendment to the Education Act, Section 9a is a drastic and unfortunate retrogressive step for the individual rights of children (Fladberg, 2017). Thus, one is led to summarily conclude that children who are bullied in Norway have in practice had little voice, though it exists in legislation. Further, given the recent amendments to the Education Act, the provision of legal voice may seem like a receding legal possibility still. Interpreting the Government's new changes in light of the political discussion on ratification of OP3 CRC leads one to surmise that OP3 CRC ratification may help to revisit domestic complaints procedures available to children in Norway. Ratification of this instrument would necessitate more substantive changes in complaints procedures for children in order to make them more effective, failing which, the child could complain directly to the CRC Committee.

The limited measures adopted, viewed through the lens of Norwegian non-ratification of OP3 CRC, illustrate ratification would thus not only signal a positive-even if only symbolic-attestation to the principles contained in the child's right to be heard, it would also strenghten the domestic complaint procedures available to children subjected to bullying in Norway. In its national report submitted to the Human Rights Council for the Universal Periodic Review, the Norwegian government specified one of its national priorities as being to "Consider ratification of the optional protocols on establishing an individual complaints mechanism for the...UN Convention on the Rights of the Child" (National report submitted in accordance with paragraph 5 of the annex to Human Rights Council resolution 16/21, 2014, para. 116). In the Review, the Human Rights Council made the formal recommendations that Norway consider becoming a party to, and to "accelerate the process of ratification" of OP3 CRC (National report submitted in accordance with paragraph 5 of the annex to Human Rights Council resolution 16/21, 2014, para. 131). However, in 2016 the Norwe- 
gian government unequivocally stated it will not give children the right to appeal to the UN. The argument was a political one, arguing "that it is highly uncertain what consequences the schemes may have for Norway's political manoeuvre" as argued by Foreign Minister Brende ("The government will not give children the right to appeal to the UN," 2016), thereby crystallising decades of arguments being made in Norway on democratic legitimacy. Though presenting itself as a pioneer in children's rights, Norwegian government measures to combat bullying read in tandem with non-ratification of OP3 CRC offer an example of the lip service granted to child rights (by adults) without affording concrete complaint rights to children-thereby failing to take seriously the right of the child to be heard-as per Article 12 .

OP3 CRC materialises Article 12(2) of the CRC, though it was not expressed in these terms during the drafting process in the Working Group Sessions in Geneva. By expressly rejecting ratification of this new instrument, the Norwegian government has in effect demonstrated its lack of commitment to Article 12(2) of the CRC and the legal agency of children. This is supported by the argument advanced here, that the most recent amendments to the Education Act Section 9a, are a step backwards for the legal agency of children. Thus, ratification would send a positive signal by the Norwegian government, thereby taking a step towards fulfilling one of the purposes of incorporation of the $\mathrm{CRC}$, by realising the rights mandated by Article 12.

This article has argued for the forging of the connection between a child's voice and agency: that, where it was implicit, it can now be seen to be an express right of children in international human rights law. This argument is no more radical than a reading of Article 12 as granting child participation rights, rights which "have been held up as the most radical and controversial contribution of the UNCRC" (Tisdall, 2015, p. 196). Antibullying efforts in Norway have been pioneering, but children's voices are still not being heard. Studies have shown the delay in the processing of bullying complaints, the extremely low rates of Section 9a decisions rendered by schools and the low usage of appeals to the County Governors, all of which are confirmed by the Djupedal Report. As we have seen here, they are also reflected in the informal complaints submitted by children to the Ombudsman for Children, especially in the cases where these children's bullying complaints are not formally registered by the school system, and are therefore invisible. The Ombudsman for Children's lack of a mandate to hear cases results in these children often being given formulaic responses, referring them to the County Governor, to the police, or back to their schools. The children are speaking, but they are not being heard in a way that would satisfy Article 12. Thus, in Norway, we are currently witnessing what can be called the "voice-over" effect, which operates as a barrier that prevents children from having voice and agency. This "voice-over" is to be distinguished from voicelessness in a recognisable way: children are publicly afforded the right to speak, and Norway is seen to be effective in its implementation of Article 12 and the child's right to be heard in matters that affect her. Rather, children are not being heard and yet they appear to have voice. The child's voice is not being substantively heard by the schools or through the lengthy appeals procedure to the County Governor. The Djupedal Report proposes substantive reform to Section 9a in order to realise Article 12, but to date, these have not been adopted by the Government in Prop. $57 \mathrm{~L}$ the revised law that entered into force 1 August 2017. The voice is thus a voice-over by decision-makers: adults in positions of political and social power claim that children have the right to be heard, whereas, to the contrary, children's complaints are in substance not being heard.

This political disenfranchisement of children in addition to their legal disabilities in claiming violations of their human rights magnifies the impenetrability of their voices through these double soundproofing layers. They are not silent, but are silenced, and are presided over by the voice-over of adult narrators: either the adult survivors of childhood violations themselves, or by adults in positions of authority, such as teachers, guardians, school principals, politicians, judges or the like.

Norway has been hailed as norm entrepreneur in world politics in human rights and anti-bullying efforts and sees itself as a leader in child rights protection. However, recent debates surrounding the OP3 CRC and the unwillingness of the executive to ratify signal a palpable sea change. Norway advances a number of political arguments as to non-ratification of OP3 CRC, not least of which is the democratic legitimacy debate. Yet, this article suggests that non-ratification can be seen rather to be more consistent with domestic practice of not granting legal agency to children, thereby not satisfying one of the central pillars of the CRC - the child's right to be heard. This can be explained in terms of the unshakeable quality of childhood legal disabilities-even in Norwaywhere children are in effect denied legal agency through their inability to complain about rights abuses as per Article 12.

\section{Acknowledgements}

The author would like to thank Torunn Marie $\varnothing$ vregaard at the Norwegian Centre for Human Rights for her research assistance.

\section{Conflicts of Interests}

The author declares no conflict of interests.

\section{References}

Andenæs, K., \& Møller, J. (2016). Retten i skolen: mellom pedagogikk, juss og politikk. Oslo: Universitetsforl.

Cantwell, N. (2011). Are children's rights still human? In J. M. Williams \& A. Invernizzi (Eds.), The Human 
rights of children : From visions to implementation (pp. 37-60). Farnham: Ashgate.

Clark, S. (2015). Child rights and the movement from status to agency: Human rights and the removal of the legal disabilities of vulnerability. Nordic Journal of International Law, 84(2), 183-220.

Day of Discussion on the right of the child to be heard. (2006). Geneva: United Nations. Retrieved from http://www.ohchr.org/Documents/HRBodies/CRC/ Discussions/Recommendations/Recommendations 2006.doc

Djupedal, Ø., \& Norge, K. (2015). Å høre til : Virkemidler for et trygt psykososialt skolemiljø : Utredning fra utvalg oppnevnt ved kongelig resolusjon 9. august 2013 : Avgitt til Kunnskapsdepartementet 18. mars 2015 (Vol. NOU 2015:2). Oslo: Departementenes sikkerhets- og serviceorganisasjon, Informasjonsforvaltning.

Fladberg, K. L. (2017). Ny mobbelov svekker barna. Dagavisen. Retrieved from http://www.dagsavisen.no/ innenriks/ny-mobbelov-svekker-barna-1.944435

Fortin, J. (2009). Children's rights and the developing law (3rd ed.). Cambridge: Cambridge University Press.

General Comment No. 5 (2003) General measures of implementation of the Convention on the Rights of the Child (arts. 4, 42 and 44, para. 6). (CRC/GC/2003/5). (2003). Geneva: United Nations.

General Comment No. 12 (2009) The right of the child to be heard. (CRC/C/GC/12). (2009). Geneva: United Nations.

General Comment No. 14 (2013) on the right of the child to have his or her best interests taken as a primary consideration (art. 3, para. 1). (CRC/C/GC/14). (2013). Geneva: United Nations.

General comment No. 16 (2013) on State obligations regarding the impact of the business sector on children's rights. (CRC/C/GC/16). (2013). Geneva: United Nations.

General comment No. 20 (2016) on the implementation of the rights of the child during adolescence. (CRC/C/GC/20). (2016). Geneva: United Nations.

Hart, R. A. (1997). Children's participation: The theory and practice of involving young citizens in community development and environmental care. London: Earthscan.

Ingebritsen, C. (2002). Norm entrepreneurs: Scandinavia's role in world politics. Cooperation and Conflict, 37(1), 11-23. doi:10.1177/00108367020370 01689

Ingebritsen, C. (2006). Scandinavia in world politics. Lanham: Rowman \& Littlefield.

Joint General Recommendation No. 31 / General Comment No. 18 on harmful practices. (CEDAW/C/GC/31CRC/C/GC/18). (2014). Geneva: United Nations.

Lundy, L. (2007). "Voice" is not enough: Conceptualising Article 12 of the United Nations Convention on the
Rights of the Child. British Educational Research Journal, 33(6), 927-942.

Lundy, L., Kilkelly, U., Byrne, B., \& Kang, J. (2012). The UN convention on the rights of the child: A study of legal implementation in 12 countries. Retrieved from http://www.unicef.org.uk/documents/publications/ unicefuk_2012crcimplentationreport.pdf

National report submitted in accordance with paragraph 5 of the annex to Human Rights Council resolution 16/21. (A/HRC/WG.6/19/NOR/1). (2014). Geneva: United Nations.

Norway proves itself a true champion of children's rights with record donation. (2014). Retrieved from https://www.unicef.org/media/media_73749.html

Norway's official websites abroad. (2016). Norway in the United Kingdom.

Parkinson, P., \& Cashmore, J. (2008). The voice of a child in family law disputes. Oxford: Oxford University Press.

Schaffer, J. K. (2015). Mellan aktivism och ambivalens: Norden och de mänskliga rättigheterna [Between Activism and Ambivalence: The Nordic States and Human Rights]. Retfærd. Nordisk Juridisk Tidsskrift.

Silberling, B. (Writer). (2004). A Series of Unfortunate Events [Film]. In L. MacDonald, W. Parkes, \& J. Van Wyck (Producer): Paramount Pictures.

Stortinget.no. (2013). Skriftlig spørsmål - stortinget.no. (2013/05/28/15:49:39). Retrieved from http:// www.stortinget.no/no/Saker-og-publikasjoner/Spor smal/Skriftlige-sporsmal-og-svar/Skriftlig-sporsmal/ ?qid $=48435$

The government will not give children the right to appeal to the UN. (2016, 30 September 2016). Nettavisen. Retrieved from http://www.nettavisen.no/ nyheter/regjeringen-sier-nei-til-fn-klageordninger/34 23267889.html

Tisdall, E. K. M. (2015). Children and young people's participation: A critical consideration of Article 12. In W. Vandenhole, E. Desmet, D. Reynaert, \& S. Lembrechts (Eds.), Routledge international handbook of children's rights studies (pp. 185-200). Oxon: Routledge.

Vandenhole, W. (2015). Children's rights from a legal perspective: Children's rights law. In W. Vandenhole, E. Desmet, D. Reynaert, \& S. Lembrechts (Eds.), Routledge international handbook of children's rights studies (pp. 27-42). Oxon: Routledge.

Wakefield, E. (2007). Norway: Anti-bullying. How do they do it in...? Lambent Productions.

Welstad, T., \& Warp, S. (2010). Realisering av elevenes rett til et godt psykososialt miljø i skolen og et elevombuds rolle: Utredning av opplæringslovens kapittel 9a og behovet for å opprette et permanent elevombud. Retrieved from https://www.regjeringen.no/ globalassets/upload/kd/vedlegg/grunnskole/utredn ingmobbeombud.pdf 


\section{About the Author}

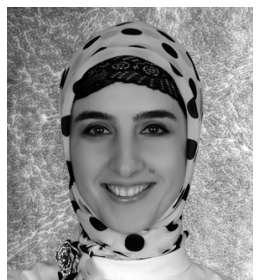

Sevda Clark is a Doctoral Research Fellow at the Norwegian Centre for Human Rights, Faculty of Law, University of Oslo. Her research addresses the legal subject, focusing specifically on child rights and the rights of people with disabilities. She is a lawyer, and serves on the Editorial Advisory Board of the Human Rights Education Review. Sevda has helped pioneer the development of new international legal standards by participating in the drafting of the third Optional Protocol to the Convention on the Rights of the Child. 